NBER WORKING PAPER SERIES

\title{
A MONETARY POLICY RULE FOR AUTOMATIC PREVENTION OF A LIQUIDITY TRAP?
}

\author{
Bennett T. McCallum \\ Working Paper 11056 \\ http://www.nber.org/papers/w11056 \\ NATIONAL BUREAU OF ECONOMIC RESEARCH \\ 1050 Massachusetts Avenue \\ Cambridge, MA 02138 \\ January 2005
}

The author is indebted to Vitor Gaspar, Stefan Gerlach, Marvin Goodfriend, James Harrigan, Edward Nelson, Maurice Obstfeld, and Vincent Reinhart for helpful comments. The views expressed herein are those of the author(s) and do not necessarily reflect the views of the National Bureau of Economic Research.

(C) 2005 by Bennett T. McCallum. All rights reserved. Short sections of text, not to exceed two paragraphs, may be quoted without explicit permission provided that full credit, including (C) notice, is given to the source. 
A Monetary Policy Rule for Automatic Prevention of a Liquidity Trap

Bennett T. McCallum

NBER Working Paper No. 11056

January 2005

JEL No. E52, E3, F41

\begin{abstract}
In analyses of "liquidity trap" problems associated with the zero lower bound (ZLB) on nominal interest rates, it is important to emphasize the difference between policy rule changes, intended to help escape an existing ZLB situation, and maintained policy rules designed so as to avoid ZLB situations. Analysis assuming that rule changes would lead to a new RE equilibrium immediately seems implausible. Accordingly, the paper focuses on the design of a rule that should retain stabilization effectiveness even if the economy is temporarily shocked into a ZLB situation.
\end{abstract}

The rule considered is one that uses as its instrument variable a weighted average of an interest rate and the rate of depreciation of the nominal exchange rate. With a small weight attached to the depreciation term, it will be nearly irrelevant in normal situations but call for strong adjustments when the ZLB condition prevails. Stabilizing properties of this "MC" rule are studied within a small open economy model developed by McCallum and Nelson. Results indicate that under ZLB conditions the MC rule will provide strong stabilizing policy actions yet, under conditions such that the ZLB constraint is not relevant, the MC rule need not hinder monetary policy.

\author{
Bennett T. McCallum \\ Graduate School of \\ Industrial Administration \\ Carnegie-Mellon University \\ Pittsburgh, PA 15213 \\ and NBER \\ bmcallum@cmu.edu
}




\section{Introduction}

Among monetary economists, a major topic of interest during recent years has been the possibility of a liquidity trap, i.e., a situation in which monetary policy stimulus cannot be obtained by the usual method of lowering the setting of the central bank's interest rate instrument because that rate is at its lower bound of zero. It would be better, I suggest, to use the term "zero lower bound situation," rather than "liquidity trap," since the latter seems to imply a priori that there is no available mechanism for generating monetary policy stimulus. In any event, dozens of papers on the subject have appeared, including notable items by Rotemberg and Woodford (1997), Wolman (1998), Krugman (1998), Reifschneider and Williams (1999), McCallum (2000), Goodfriend (2000), Orphanides and Williams (2000), Svensson (2001), Benhabib, Schmitt-Grohe, and Uribe (2001), Jung, Teranishi, and Watanabe (2001), Coenen and Wieland (2003), Woodford (2003), Eggertsson and Woodford (2003, 2004), and Auerbach and Obstfeld (2003, 2004). Recent experiences in Japan have, of course, added intense concern from the practical perspective.

One of the more prominent results to come out of this literature is an irrelevance proposition pertaining to open-market purchases, put forth by Eggertsson and Woodford (2003), according to which "quantitative easing" is to no avail. Instead, "the key to effective central-bank action to combat a deflationary slump is the management of expectations" (2003, p. 8). At face value, this proposition seems to contradict results by Auerbach and Obstfeld (2003), Coenen and Wieland (2003), and others who find a role for open market purchases of "unconventional" assets. ${ }^{1}$ It will be argued below, however, that there is no actual theoretical inconsistency; that the different papers presume different types of policy 
experiments. $^{2}$ One crucial distinction is whether or not the policy experiment considered involves a change in the policy rule. If there is a credible rule change in an expansionary direction, then—as is shown below—monetary policy can be effective in bringing an economy out of a zero lower bound (ZLB) situation.

This last statement supposes, however, that the policy change in question is fully understood and believed so that a new rational expectations equilibrium becomes operative immediately. This, however, appears to be a highly dubious proposition. Accordingly, it would seem to be of some importance to consider how a central bank could regularly follow a policy rule that, if sustained, would keep the economy out of a ZLB situation automatically. A major objective of the present paper is, accordingly, to develop one such rule. That task will be undertaken in Section 3, after Section 2 begins by expanding upon the topics just mentioned. Then in Sections 4 and 5 a small open economy model, based on optimizing behavior but with nominal price stickiness, will be specified and calibrated. Simulation results with this model and variants of our proposed policy rule are reported in Section 6, so as to explore the properties of the rule (which are found to be highly promising). Two relevant theoretical issues are discussed in Section 7 and a brief conclusion follows.

\section{$\underline{\text { 2. Alternative Policy Experiments }}$}

It is expositionally useful to begin with the policy experiment of Eggertsson and Woodford (2003), henceforth referred to as E\&W. It involves analysis of the stabilization properties of an interest rate policy regime that is specified to incorporate "quantitative easing." That term is taken by $\mathrm{E} \& \mathrm{~W}$ (2003) to mean that the monetary base supply function, which supports (i.e., implements) their interest rate rule given money demand behavior,

\footnotetext{
${ }^{1}$ Assets, that is, that are not perfect substitutes for the short-term security that is normally used in open market operations.
} 
includes an unusual nonlinear component that calls for extra open market purchases

whenever the interest rate is zero. These purchases are evidently reversed, however, as soon as the interest rate rises above zero. (The interest rate in question, denoted $\mathrm{R}_{\mathrm{t}}$, is "the riskless nominal interest rate on one-period obligations...” (E\&W 2003, p. 10)) One could simply view this function as a base-money-supply policy rule, include the base money stock as a variable, and solve the model in a standard and familiar RE fashion, if it were not for the non-linear component and the restriction that the interest rate must be non-negative. ${ }^{3}$ What $\mathrm{E} \& \mathrm{~W}$ do with the resulting model is to show that the behavior of prices and output in the model's RE equilibrium is independent of the parameters that describe the quantitativeeasing component of the base supply rule. Whatever the extent of the additional base-money supply specified by this component, then, there will be no effect on inflation or output in the RE equilibrium. That is the $\mathrm{E} \& \mathrm{~W}$ irrelevance proposition. Note, crucially, that it pertains to the nature of a single ongoing RE equilibrium for a given policy rule that involves certain specified behavior when the ZLB is operative, not to the adoption of a new rule. The irrelevance proposition is arguably not surprising, given that any "extra" base money supplied when $\mathrm{R}_{\mathrm{t}}=0$ is removed immediately as soon as $\mathrm{R}_{\mathrm{t}}>0 .{ }^{4}$

The policy experiment considered by Auerbach and Obstfeld (2003) is quite different. It begins with a policy rule in place, one that specifies a constantly growing level of the monetary base, and the economy in a ZLB situation with the interest rate $\mathrm{R}_{\mathrm{t}}$ equal to zero. Then the authors postulate a change in the base money rule, either a one-time upward shift in

\footnotetext{
${ }^{2}$ This point is also made by Eggertsson and Woodford (2003, 2004), but with a different emphasis.

${ }^{3}$ The model used by $\mathrm{E} \& \mathrm{~W}$ is rather standard, relative to the recent monetary policy literature, but is slightly more "monetarist" than most in that the utility function, which includes real money balances as an argument, is not assumed to be separable.

${ }^{4}$ It is my impression that proponents of quantitative easing for Japan have almost invariable had in mind a new policy that, among other features, would entail a target inflation rate high enough to imply a positive steadystate interest rate on overnight bank loans.
} 
the path of the base or an increase in its slope (the rate of growth of the base)-in either case a change that is sustained permanently. The experiment presumes a forseen upward jump in the natural real rate of interest after 5 periods that would bring the ZLB episode to an end in any event, but each of the two considered policy rule changes would have effects on the path of prices and possibly output in the interim. The increased base growth-rate policy also has the effect of bringing the ZLB episode with $R_{t}=0$ to an end sooner than would otherwise be the case. The Auerbach and Obstfeld results are of particular interest because the model utilized is in most respects similar to that of E\&W.

In light of the foregoing discussion, I would suggest that the basic difference in outcomes is that the $\mathrm{E} \& \mathrm{~W}$ experiment concerns the effects of an unusual design feature of one maintained policy rule whereas the Auerbach and Obstfeld experiment has to do with effects of a change from one policy rule to another. In one case the monetary rule utilizes an interest rate instrument and in the other case the monetary base, but it appears that this distinction is not crucial. As hinted above, E\&W could utilize a policy rule specified as a base rule that includes an analogous quantitative easing component and develop a similar irrelevance result for that case. Furthermore, for a change in a monetary rule to be effective when an economy is in a ZLB situation, it is not necessary for the rule to be one that governs base quantities; it could as well be an interest rate rule that is altered.

For an extremely simple illustration of this last point, it will be sufficient to use a closed-economy model with full price flexibility. Consider the following two-equation system, which is so familiar as to require very little explanation at this point: ${ }^{5}$

\footnotetext{
${ }^{5}$ Explanation of a model that includes (1)(2) as a special case will be provided below. The present system differs from the model of $\mathrm{E} \& \mathrm{~W}$ primarily by positing flexible prices, which is irrelevant to the current point.
} 
(1) $\quad \mathrm{y}_{\mathrm{t}}=\mathrm{b}_{0}+\mathrm{b}_{1}\left(\mathrm{R}_{\mathrm{t}}-\mathrm{E}_{\mathrm{t}} \Delta \mathrm{p}_{\mathrm{t}+1}\right)+\mathrm{E}_{\mathrm{t}} \mathrm{y}_{\mathrm{t}+1}+\mathrm{v}_{\mathrm{t}}$

(2) $\quad \mathrm{R}_{\mathrm{t}}=\mu_{0}+\Delta \mathrm{p}_{\mathrm{t}}+\mu_{1}\left(\Delta \mathrm{p}_{\mathrm{t}}-\pi^{*}\right)+\mu_{2} \mathrm{y}_{\mathrm{t}}$

Here $\mathrm{y}_{\mathrm{t}}$ and $\mathrm{p}_{\mathrm{t}}$ denote the logs of an output variable and the price level so $\Delta \mathrm{p}_{\mathrm{t}}$ is inflation while $\mathrm{R}_{\mathrm{t}}$ is the one-period nominal interest rate. The term $\mathrm{v}_{\mathrm{t}}$ represents a preference shock that is generated by an exogenous stochastic process, which is assumed to be AR(1) - i.e., autoregressive of order one-with parameter $\rho$. Equation (2) is a Taylor-style rule in which the central bank is depicted as setting an interest rate instrument $\mathrm{R}_{\mathrm{t}}$ each period so as to tighten policy when inflation exceeds its target value $\pi^{*}$ and/or when output is high. In (1)(2), $y_{t}$ should be interpreted as the output gap, $y_{t}-\bar{y}_{t}$, with $\bar{y}_{t}$ for simplicity assumed constant at the value zero. With flexible prices we then have $y_{t}=0$ in each period. Thus there are only two endogenous variables to be determined by the system, $\mathrm{R}_{\mathrm{t}}$ and $\Delta \mathrm{p}_{\mathrm{t}}$. This model should be understood to also include the requirement that $\Delta \mathrm{p}_{\mathrm{t}}$ must not approach $-\infty$ as $\mathrm{t} \rightarrow \infty$, because of a transversality condition that obtains in the underlying optimizing model.

To obtain a rational expectations (RE) solution, we first substitute out $\mathrm{R}_{\mathrm{t}}$ and using $\mathrm{y}_{\mathrm{t}}=0$ obtain

$$
0=\mathrm{b}_{0}+\mathrm{b}_{1}\left[\mu_{0}-\mu_{1} \pi^{*}+\left(1+\mu_{1}\right) \Delta \mathrm{p}_{\mathrm{t}}-\mathrm{E}_{\mathrm{t}} \Delta \mathrm{p}_{\mathrm{t}+1}\right]+\mathrm{v}_{\mathrm{t}}
$$

The minimum state variable (MSV) solution is of the form

$$
\Delta \mathrm{p}_{\mathrm{t}}=\phi_{0}+\phi_{1} \mathrm{v}_{\mathrm{t}}
$$

implying $\mathrm{E}_{\mathrm{t}} \Delta \mathrm{p}_{\mathrm{t}+1}=\phi_{0}+\phi_{1} \rho \mathrm{v}_{\mathrm{t}}$. Then substitution into (3) and application of a standard undetermined coefficient procedure yields the requirement that

$$
0=b_{0}+b_{1}\left[\mu_{0}-\mu_{1} \pi^{*}+\left(1+\mu_{1}\right)\left(\phi_{0}+\phi_{1} v_{t}\right)-\phi_{0}-\phi_{1} \rho v_{t}\right]+v_{t}
$$


holds identically for all realizations of $\mathrm{v}_{\mathrm{t}}$. That implies unique values for $\phi_{0}$ and $\phi_{1}$ and yields the MSV solution

$$
\Delta \mathrm{p}_{\mathrm{t}}=\pi^{*}-\left(\mathrm{b}_{0}+\mathrm{b}_{1} \mu_{0}\right) / \mu_{1}-\left[\mathrm{b}_{1}\left(1-\rho+\mu_{1}\right)\right]^{-1} \mathrm{v}_{\mathrm{t}} .
$$

Of course, Taylor (1993) and many others prescribe that the central bank set $\mu_{0}=r$, the longrun average real rate of interest, and we observe from (1) that this rate equals $-b_{0} / b_{1}$. So adherence to this recommendation implies that the second term on the right-hand side of (6) vanishes and we have $\Delta \mathrm{p}_{\mathrm{t}}=\pi^{*}-\left[\mathrm{b}_{1}\left(1-\rho+\mu_{1}\right)\right]^{-1} \mathrm{v}_{\mathrm{t}}$ as the MSV solution for inflation.

Suppose, then, that an economy is of form (1)(2) except that it also includes the requirement that $R_{t} \geq 0$. Then (6) would be the RE solution if the parameter values and the distribution of $\mathrm{v}_{\mathrm{t}}$ were such that this inequality was never binding. But suppose that such is not the case and that the economy is in a ZLB situation with $R_{t}=0$. Next, suppose that in some period there is a policy change that amounts to an increase in the target inflation rate $\pi^{*}$ to a value high enough that the ZLB will never be effective in the future. Then the new RE equilibrium will yield immediately an inflation rate high enough to escape the ZLB situation. By contrast, an increase in the value of the policy parameter $\mu_{1}$ would in that situation have no necessarily constructive effect toward bringing the economy out of the ZLB. ${ }^{6}$ This contrast is analogous to that of the Auerbach-Obstfeld and E\&W results.

The simplicity and starkness of the foregoing example will probably lead many readers to object, to say something like "But that is totally implausible; the economy's agents would be very unlikely to know about, understand, and believe in the policy change even if

\footnotetext{
${ }^{6}$ The solution for $\mathrm{R}_{\mathrm{t}}$ is $\mathrm{R}_{\mathrm{t}}=\mathrm{r}+\pi^{*}-\left[\left(1 / \mathrm{b}_{1}\right)\left(1+\mu_{1}\right) /\left(1-\rho+\mu_{1}\right)\right] \mathrm{v}_{\mathrm{t}}$. Here the coefficient on $\mathrm{v}_{\mathrm{t}}$ is positive, but the direction of effect depends upon the sign of $v_{t-1}$. Furthermore, if $\rho=0$, the magnitude of the coefficient is independent of $\mu_{1}$. Alternatively, one might ask whether an increased value of $\mu_{1}$ would, with a sustained rule, help to prevent ZLB situations. The simulation results presented below suggest that the answer is "no," since larger values of $\mu_{1}$ evidently imply (given other parameter values) increased variability of $R_{t}$.
} 
the central bank has every intention of carrying it out." With that objection I would entirely agree. More generally, many proponents of the hypothesis of rational expectations find it attractive mainly for consideration of alternative maintained policy rules, i.e., for application to situations prevailing after some time has passed (since any previous rule change) and the economy has settled into a new stochastic equilibrium. To these economists-e.g., Lucas (1980, p. 205), Lucas and Sargent (1981, p. xxxvii), Kydland and Prescott (1977) — immediate application of RE after a policy change seems dubious. Partly for this reason, E\&W (2003), McCallum (2000), Jung, Teranishi, and Watanabe (2001), Reifschneider and Williams (2000) and a few others have concentrated attention on rules for preventing a ZLB situation, rather than (or in addition to) schemes for escaping a ZLB "trap" in which an economy finds itself. In that spirit we move on to the discussion of a new rule proposal. ${ }^{7}$

\section{A Rule for Use At or Away From the ZLB}

Let us now turn to the main topic of the present paper, which is the development and exploration of a monetary policy rule that is appropriate for use at all times, whether or not short-term nominal interest rates are at their ZLB. ${ }^{8}$ The very simple basic idea is to combine two component rules, designed for normal and ZLB conditions, by means of a weighted average of their respective instrument settings. The first of these two component rules could be written as a standard Taylor-type formulation as follows:

$$
\mathrm{R}_{\mathrm{t}}=\mathrm{r}+\Delta \mathrm{p}_{\mathrm{t}}+\mu_{1}\left(\Delta \mathrm{p}_{\mathrm{t}}-\pi^{*}\right)+\mu_{2}\left(\mathrm{y}_{\mathrm{t}}-\overline{\mathrm{y}}_{\mathrm{t}}\right)+\mathrm{e}_{\mathrm{t}}, \quad \quad \mu_{1}, \mu_{2} \geq 0
$$

Here $\mathrm{R}_{\mathrm{t}}$ is a short-term nominal interest rate instrument and, for simplicity, we have entered

\footnotetext{
${ }^{7}$ There is some interest in a policy of "helicopter drops," i.e., repeated gifts of money to the public, in contrast to monetary policy actions that involve only open-market actions by the central bank. A brief analysis is presented in Appendix A.

${ }^{8}$ Obviously, if such a rule is in force during a ZLB episode, there is no need to devise an "exit strategy."
} 
the current value of inflation and the output gap as the variables to which the rule responds. ${ }^{9}$ In (7) $\pi^{*}$ is the target for inflation and $\mathrm{r}$ is the long-term average real rate of interest, while $\mathrm{e}_{\mathrm{t}}$ is a random policy shock that reflects unsystematic behavior by the monetary authority. We suppose that in normal times, when the ZLB on $\mathrm{R}_{\mathrm{t}}$ is not binding, the central bank wishes to utilize (7) as its monetary policy rule, so as to keep $\Delta \mathrm{p}_{\mathrm{t}}$ close to $\pi^{*}$ and $\mathrm{y}_{\mathrm{t}}$ close to $\overline{\mathrm{y}}_{\mathrm{t}}$ on average.

When $R_{t}$ is at its lower bound of zero, however, the central bank will be unable to respond as implied by (7) if the gap measures $\Delta \mathrm{p}_{\mathrm{t}}-\pi^{*}$ and $\mathrm{y}_{\mathrm{t}}-\overline{\mathrm{y}}_{\mathrm{t}}$ together call for a reduction in $\mathrm{R}_{\mathrm{t}}$. In previous work, including McCallum (2000) and (2003), I have accordingly suggested a rule for adjusting the foreign exchange rate, $\mathrm{s}_{\mathrm{t}}$ in logarithmic terms, in such occasions. The version of this rule given in the more recent of these two papers is as follows:

$$
\Delta \mathrm{s}_{\mathrm{t}}=\Delta \mathrm{q}+\Delta \mathrm{p}_{\mathrm{t}}-\mu_{1}\left(\Delta \mathrm{p}_{\mathrm{t}}-\pi^{*}\right)-\mu_{2}\left(\mathrm{y}_{\mathrm{t}}-\overline{\mathrm{y}}_{\mathrm{t}}\right)-\mathrm{e}_{\mathrm{t}}, \quad \mu_{1}, \mu_{2} \geq 0
$$

Here we have minus signs on the two gap measures because an increase in the value of $\Delta \mathrm{s}_{\mathrm{t}}-\Delta \mathrm{p}_{\mathrm{t}}$ represents a loosening, not a tightening, of monetary policy. ${ }^{10}$

Next we take a weighted average of the two preceding expressions, after changing the signs on all terms in (8). Let $1-\theta$, with $0 \leq \theta \leq 1$, be the weight on the $\mathrm{R}_{\mathrm{t}}$ instrument. Then the resulting rule is as follows:

$$
\left[(1-\theta) R_{t}+\theta\left(-\Delta s_{t}\right)\right]=(1-\theta) r-\theta \Delta q+(1-2 \theta) \Delta p_{t}+\mu_{1}\left(\Delta p_{t}-\pi^{*}\right)+\mu_{2}\left(y_{t}-\bar{y}_{t}\right)+e_{t} .
$$

To facilitate understanding of the latter, first suppose that that the interest rate $\mathrm{R}_{\mathrm{t}}$ equals zero, i.e., is at its ZLB. Then (9) becomes a rule for setting the value of the rate of exchange rate

\footnotetext{
${ }^{9}$ It would be possible to use instead expected future values or lagged expectations of current values, etc.
} 
depreciation, $\Delta \mathrm{s}_{\mathrm{t}}$. The formula might look a bit strange, but when $\mathrm{R}=0$, an implied steadystate relationship is $r=-\Delta p$. Then using the latter with (9) and rearranging we obtain

$$
\Delta \mathrm{s}_{\mathrm{t}}=\Delta \mathrm{q}+\Delta \mathrm{p}_{\mathrm{t}}-\left(\mu_{1} / \theta\right)\left(\Delta \mathrm{p}_{\mathrm{t}}-\pi^{*}\right)-\left(\mu_{2} / \theta\right)\left(\mathrm{y}_{\mathrm{t}}-\overline{\mathrm{y}}_{\mathrm{t}}\right)-(1 / \theta) \mathrm{e}_{\mathrm{t}}
$$

Clearly, the latter is of exactly the same form as the $\Delta \mathrm{s}_{\mathrm{t}}$ rule (8), although it has a different numerical value for two of the response coefficients.

What about the interpretation of (9) when $R_{t}$ is not at the ZLB? To gain an intuitive idea regarding this case, suppose that the nominal exchange rate were to behave in conformity with the current inflation rate and the long run average rate of real exchange rate depreciation. Suppose, that is, that $\Delta \mathrm{s}_{\mathrm{t}}=\Delta \mathrm{p}_{\mathrm{t}}+\Delta \mathrm{q}$ holds on a period-by-period basis. Then substitution into (9) yields

$$
\mathrm{R}_{\mathrm{t}}=\mathrm{r}+\Delta \mathrm{p}_{\mathrm{t}}+\left(\mu_{1} /(1-\theta)\right)\left[\Delta \mathrm{p}_{\mathrm{t}}-\pi^{*}\right]+\left(\mu_{2} /(1-\theta)\right)\left[\mathrm{y}_{\mathrm{t}}-\overline{\mathrm{y}}_{\mathrm{t}}\right]+(1 /(1-\theta)) \mathrm{e}_{\mathrm{t}}
$$

which has the form of a standard Taylor-type rule! So (9) works in a highly intuitive manner in both of these reference cases

How would the composite rule (9) be implemented? To do so, the central bank would each period make purchases (or sales) in the money market or foreign exchange market—or preferably both - so as to adjust $(1-\theta) \mathrm{R}_{\mathrm{t}}-\theta \mathrm{s}_{\mathrm{t}}$ to the value indicated by (9), taking $\mathrm{s}_{\mathrm{t}-1}$ as given. In this regard, note that buying money market securities tends to drive $\mathrm{R}_{\mathrm{t}}$ downward and $\mathrm{s}_{\mathrm{t}}$ upward, so both components of the weighted average $\left[(1-\theta) \mathrm{R}_{\mathrm{t}}+\theta\left(-\Delta \mathrm{s}_{\mathrm{t}}\right)\right] \equiv \mathrm{MC}_{\mathrm{t}}$ move in the same (downward) direction. Alternatively, buying foreign exchange would tend to drive $\mathrm{s}_{\mathrm{t}}$ upward and $\mathrm{R}_{\mathrm{t}}$ downward, so again both components move in the desired direction.

\footnotetext{
${ }^{10}$ Here and in what follows $S_{t}=\log ^{-1} \mathrm{~S}_{\mathrm{t}}$ is the home country price of foreign exchange. Also, $\Delta \mathrm{q}$ is the trend rate of growth of the real exchange rate minus the average inflation rate abroad.
} 
Clearly, when instead a monetary tightening is desired, it would be possible to sell money market securities and/or foreign exchange, moving $\mathrm{MC}_{\mathrm{t}}$ in the upward direction. ${ }^{11}$

Since the rule is designed to be used at all times, operational procedures should be the same both at and away from the ZLB, so that market participants will understand that one rule is in effect. Accordingly, it would be desirable to have a secondary rule for determining what fraction of open market purchases will, during a given period, be made in the foreign exchange market. One possibility would be to have a fixed fraction, such as 0.25 . (Note that this fraction does not need to equal $\theta$, and probably should not.) Such an arrangement would imply that that the central bank would be making a large volume of purchases from the money market when at the ZLB, even though those purchases would not (in principle) have any effect on the value of $\mathrm{MC}_{\mathrm{t}}$. Other rules that would increase the fraction as $\mathrm{R}_{\mathrm{t}}$ gets closer to zero would not have this latter property, but would be more difficult for market participants to understand.

It is likely that at this point many readers will have guessed the reason for using the symbol $\mathrm{MC}_{\mathrm{t}}$ to denote our composite measure. It is that this measure has some resemblance to a "monetary conditions index." The latter concept has been viewed rather unfavorably by most monetary economists in recent years, but that does not necessarily make it an undesirable policy indicator. It is my impression that the typical mode of presentation has made the concept appear to be dimensionally incoherent, ${ }^{12}$ for most proponents have used written expressions such as $(1-\theta) R_{t}-\theta s_{t}$, rather than $(1-\theta) R_{t}+\theta\left(-\Delta s_{t}\right) .{ }^{13}$ But in such cases

\footnotetext{
${ }^{11}$ Of course there are limits on a central bank's ability to increase $\mathrm{MC}_{\mathrm{t}}$, since it will hold only finite stocks of foreign and domestic assets.

${ }^{12}$ Thus I, for one, have been disturbed by the practice of taking a weighted average of two terms that have the units $1 /$ years and yen/dollar, for example. But if the latter is expressed in rate of change form, as in (9), it too can have the units 1/years.

${ }^{13}$ See, e.g., Ball (1999), Gerlach and Smets (2000), and the recent contribution by Detken and Gaspar (2003).
} 
the authors may actually have had in mind an exchange rate expressed in relation to some reference value, which leaves open the possibility that the dimensions of the two terms are in fact consistent. That is not to suggest that the numerical specifications of monetary conditions indexes considered or used by actual central banks have been ones that are well designed. In Section 6 below it will be argued that a very small weight - on the order of 0.025 - should be attached to the exchange rate term, whereas personal experience tells me that the Reserve Bank of New Zealand was at one time discussing a possible monetary conditions index with a weight close to $1-0.025=0.975$, i.e., one almost 40 times as large. In short, the present discussion is not intended to express approval of previous discussions of monetary condition indexes, but merely to acknowledge the extent of similarity between them and the policy rule (9) here under investigation.

Another matter that requires brief attention is the notion of interest rate smoothing, which is widely viewed as a practice much utilized by actual central banks. Can inertial behavior of $R_{t}$ be accommodated by rules such as (9)? Certainly there would be no analytical problem created by writing a partial adjustment equation for $\mathrm{MC}_{\mathrm{t}}$, with the adjustment moving the actual value of $\mathrm{MC}_{\mathrm{t}}$ toward a value such as that on the right-hand side of (9). Alternatively, one could apply smoothing only to the $R_{t}$ component, by writing (7) in a partial adjustment form before taking a weighted average of (7) and (8). ${ }^{14}$ In this case the rule would be written as

$$
\begin{aligned}
& {\left[(1-\theta) \mathrm{R}_{\mathrm{t}}+\theta\left(-\Delta \mathrm{s}_{\mathrm{t}}\right)\right]=\left(1-\mu_{3}\right)(1-\theta) \mathrm{r}-\theta \Delta \mathrm{q}-\left[(1-\theta)\left(1-\mu_{3}\right)+\theta\right] \mu_{1} \pi^{*}} \\
& \left.+\left[(1-\theta)\left(1-\mu_{3}\right)\left(1+\mu_{1}\right)+\theta\left(\mu_{1}-1\right)\right] \Delta \mathrm{p}_{\mathrm{t}}+\left[(1-\theta)\left(1-\mu_{3}\right)+\theta\right] \mu_{2}\left(\mathrm{y}_{\mathrm{t}}-\overline{\mathrm{y}}_{\mathrm{t}}\right)\right]+\mu_{3} \mathrm{R}_{\mathrm{t}-1}+\mathrm{e}_{\mathrm{t}},
\end{aligned}
$$

\footnotetext{
${ }^{14}$ If policy is "superinertial," as featured in Rotemberg-Woodford (1997) and Woodford (2003, pp. 100-101), then the partial-adjustment formulation in $\left(9^{\prime}\right)$ is not appropriate, but this does not create any difficulties for the analysis developed below.
} 
which will be used below. Here (and in what follows) $\mu_{3}$ is the interest rate smoothing parameter $\left(0<\mu_{3}<1\right)$.

\section{$\underline{\text { 4. Model Specification }}$}

In order to explore the properties of a rule such as (9) or (9'), one needs to combine it with an appropriately specified model of an economy and then conduct analytical exercises to determine how the economy is predicted to perform with different variants of the rule. Clearly the model needs to pertain to an open economy, and most contemporary analysts would prefer that it be a rational expectations model based on optimizing behavior by the economy's individual households and firms while also incorporating some form of nominal price stickiness. The model that will be used below is one that was developed by McCallum and Nelson (1999) and utilized subsequently by them (2000) in an exploration of relationships between CPI inflation and exchange rate depreciation. This "M\&N" model is not econometrically estimated, but is calibrated to match important selected characteristics of the economies of interest. It differs from many other contributions in the area, however, in the manner in which imported goods are treated. In particular, the M\&N model treats imports not as finished goods, ready for immediate consumption, but instead as raw-material inputs to the home economy's producers. This alternative modelling strategy leads to a cleaner and simpler theoretical structure, relative to the standard treatment, and is empirically attractive. Since the optimizing, general equilibrium analysis is spelled out in McCallum and Nelson (1999), here I will take an informal expository approach designed to facilitate understanding of the model's structural equations. 
It is well known that optimizing analysis leads, in a wide variety of infinite-horizon models possibly involving imperfect competition, to a consumption Euler equation that can be expressed or approximated in the form

$$
\mathrm{c}_{\mathrm{t}}=\mathrm{E}_{\mathrm{t}} \mathrm{c}_{\mathrm{t}+1}+\mathrm{b}_{0}+\mathrm{b}_{1} \mathrm{r}_{\mathrm{t}}+\mathrm{v}_{\mathrm{t}}, \quad \mathrm{b}_{1}<0
$$

where $c_{t}$ is the $\log$ of a Dixit-Stiglitz consumption-bundle aggregate $C_{t}$ of the many distinct goods that a typical household consumes in period $\mathrm{t}$. In (12), $\mathrm{r}_{\mathrm{t}}$ is the real interest rate on home-country one period bonds (private or government) and $\mathrm{v}_{\mathrm{t}}$ is a stochastic shock term that pertains to household preferences regarding present vs. future consumption. In closed economy analysis, relation (12) is often combined with a log-linearized, per-household, overall resource constraint to yield an "expectational" or "optimizing" IS function. That step presumes that investment and capital are treated as exogenous. The simplest version of that assumption is that the capital stock is fixed; since endogenizing capital greatly complicates the analysis, the constant-capital specification will be used here.

For an open-economy extension, one might be tempted to write the economy's percapita resource constraint as $y_{t}=\omega_{1} c_{t}+\omega_{2} g_{t}+\omega_{3} x_{t}-\omega_{4} i_{t}$, where $y_{t}, g_{t}, x_{t}$, and $i_{t}$ are logarithms of real output, government consumption, exports, and imports with $\omega_{1}, \omega_{2}, \omega_{3}$, and $\omega_{4}$ representing steady-state shares of output for consumption, government purchases, exports, and imports. But if imports are exclusively material inputs to the production of home-country goods, and $Y_{t}=\ln ^{-1} y_{t}$ is interpreted as units of output, not value added, then the relevant resource constraint is

$$
y_{t}=\omega_{1} c_{t}+\omega_{2} g_{t}+\omega_{3} x_{t}
$$

For import demand to be modelled in an optimizing fashion, assume that output of consumer goods is effected by producers all with production functions of the same CES 
form, with labor and material imports being the two variable inputs. Then the costminimizing demand for imports is ${ }^{15}$

$$
\mathrm{im}_{\mathrm{t}}=\mathrm{y}_{\mathrm{t}}-\sigma \mathrm{q}_{\mathrm{t}}+\text { const. }
$$

where $\sigma$ is the elasticity of substitution between materials and labor in production, and where "const." denotes some constant. ${ }^{16}$ Also, $\mathrm{q}_{\mathrm{t}}$ is the log price of imports in terms of produced consumption goods. We will refer to $\mathrm{Q}_{t}=\ln ^{-1} \mathrm{q}_{\mathrm{t}}$ as the real exchange rate. Let $\mathrm{P}_{t}$ and $\mathrm{S}_{\mathrm{t}}$ be the home country money price of goods and foreign exchange, with $\mathrm{P}_{\mathrm{t}}{ }^{*}$ the foreign money price of home-country imports. Then if $\mathrm{p}_{\mathrm{t}}, \mathrm{s}_{\mathrm{t}}$, and $\mathrm{p}_{\mathrm{t}}{ }^{*}$ are logs of these variables, we have

$$
\mathrm{q}_{\mathrm{t}}=\mathrm{s}_{\mathrm{t}}-\mathrm{p}_{\mathrm{t}}+\mathrm{p}_{\mathrm{t}}^{*}
$$

Symmetrically, we assume that export demand is given as

$$
\mathrm{x}_{\mathrm{t}}=\mathrm{yt}_{\mathrm{t}}^{*}+\sigma^{*} \mathrm{q}_{\mathrm{t}}+\text { const. }
$$

where $\mathrm{y}_{\mathrm{t}}{ }^{*}$ denotes income abroad and $\sigma^{*}$ is the price elasticity of demand from abroad for home-country goods. Since the economy is small, we take $\mathrm{y}_{\mathrm{t}}{ }^{*}$ to be exogenous.

Now consider output determination in a sticky-price version of the model. Taking a log-linear approximation to the home-country production function, we have

$$
y_{t}=\alpha_{1} a_{t}+\alpha_{1} n_{t}+\alpha_{2} i m_{t}+\text { const., }
$$

where $\mathrm{n}_{\mathrm{t}}$ and $\mathrm{a}_{\mathrm{t}}$ are logs of labor input and a labor-augmenting technology shock term, respectively. For simplicity suppose that labor supply is inelastic, with 1.0 units supplied per period by each household. Thus with full price flexibility we would have $\mathrm{n}_{\mathrm{t}}=0$ and the

\footnotetext{
${ }^{15}$ In the model used below there is also a small adjustment included for the effects of imperfect competition.

${ }^{16}$ That is, the expressions "const." in different equations appearing below will typically refer to different constant magnitudes.
} 
flexible-price, natural rate (or "potential") value of $y_{t}$ will be $\bar{y}_{t}=\alpha_{1} a_{t}+\alpha_{2} i m_{t}+$ const. so that $\bar{y}_{t}=\alpha_{1} a_{t}+\alpha_{2}\left[\bar{y}_{t}-\sigma q_{t}\right]+$ const., or

$$
\bar{y}_{t}=\left(1-\alpha_{2}\right)^{-1} \alpha_{1} a_{t}-\left[\sigma \alpha_{2} /\left(1-\alpha_{2}\right)\right] q_{t}+\text { const. }
$$

But while $\bar{y}_{t}$ would be the economy's output in period $t$ if prices could adjust promptly, we assume that prices adjust only sluggishly. Then if the economy's demand quantity as determined by the rest of the system differs from $\bar{y}_{t}$, the former quantity $y_{t}$ prevails - with workers departing from their (inelastic) supply schedules so as to provide whatever quantity is needed to produce the demanded output, with $\mathrm{im}_{\mathrm{t}}$ given by (14).

In such a setting, the precise way in which prices adjust has a direct impact on demand and consequently on production. There are various models of gradual price adjustment utilized in the recent literature that are intended to represent optimizing behavior in the context of nominal adjustment costs. In the analysis that follows, I will use

$$
\Delta \mathrm{p}_{\mathrm{t}}=(1+\beta)^{-1}\left(\beta \mathrm{E}_{\mathrm{t}} \Delta \mathrm{p}_{\mathrm{t}+1}+\Delta \mathrm{p}_{\mathrm{t}-1}\right)+\kappa\left(\mathrm{y}_{\mathrm{t}}-\overline{\mathrm{y}}_{\mathrm{t}}\right)+\mathrm{u}_{\mathrm{t}}, \quad \kappa>0
$$

where $\beta$ is a discount factor and $u_{t}$ is a behavioral disturbance. This form of equation has been fairly prominent, ${ }^{17}$ primarily because it tends to impart a more realistic degree of inflation persistence than does the Calvo-Rotemberg model (which is theoretically more attractive). For an extensive discussion of relevant issues, see Woodford (2003).

A standard feature of most open-economy models is a relation implying uncovered interest parity (UIP). Despite its prominent empirical weaknesses, accordingly, the basic M\&N model incorporates one:

$$
\mathrm{R}_{\mathrm{t}}-\mathrm{R}_{\mathrm{t}}^{*}=\mathrm{E}_{\mathrm{t}} \Delta \mathrm{s}_{\mathrm{t}+1}+\xi_{\mathrm{t}}
$$


We include a time-varying "risk premium" term $\xi_{t}$, however, that may have a sizeable variance and may be autocorrelated. In the main investigation below, moreover, a crucial departure from pure UIP will be assumed to prevail.

In previous applications of this model it has been assumed, as in most recent research in monetary economics, that the monetary authority conducts policy by adjusting a oneperiod nominal interest rate in response to prevailing (or forecasted future) values of inflation and the output gap, $\widetilde{y}_{t}=y_{t}-\bar{y}_{t}$, as in (7) above. For present purposes, however, we will be using the rule (9'), now written as

$$
\begin{aligned}
& {\left[(1-\theta) \mathrm{R}_{\mathrm{t}}+\theta\left(-\Delta \mathrm{s}_{\mathrm{t}}\right)\right]=\left(1-\mu_{3}\right)(1-\theta) \mathrm{r}-\theta \Delta \mathrm{q}-\left[(1-\theta)\left(1-\mu_{3}\right)+\theta\right] \mu_{1} \pi^{*}} \\
& \left.+\left[(1-\theta)\left(1-\mu_{3}\right)\left(1+\mu_{1}\right)+\theta\left(\mu_{1}-1\right)\right] \Delta \mathrm{p}_{\mathrm{t}}+\left[(1-\theta)\left(1-\mu_{3}\right)+\theta\right] \mu_{2}\left(\mathrm{y}_{\mathrm{t}}-\overline{\mathrm{y}}_{\mathrm{t}}\right)\right]+\mu_{3} \mathrm{R}_{\mathrm{t}-1}+\mathrm{e}_{\mathrm{t}}
\end{aligned}
$$

of which (7)—possibly with smoothing-is a special case when $\theta=0$.

To complete the model, we need only to include the Fisher identity, $\left(1+r_{t}\right)=$ $\left(1+\mathrm{R}_{\mathrm{t}}\right) /\left(1+\mathrm{E}_{\mathrm{t}} \Delta \mathrm{p}_{\mathrm{t}+1}\right)$, which we approximate in the familiar fashion:

$$
r_{t}=R_{t}-E_{t} \Delta p_{t+1}
$$

Thus we have a simple log-linear system in which the ten structural relations (12)-(21) determine values for the endogenous variables $\mathrm{y}_{\mathrm{t}}, \overline{\mathrm{y}}_{\mathrm{t}}, \Delta \mathrm{p}_{\mathrm{t}}, \mathrm{r}_{\mathrm{t}}, \mathrm{R}_{\mathrm{t}}, \mathrm{q}_{\mathrm{t}}, \mathrm{s}_{\mathrm{t}}, \mathrm{c}_{\mathrm{t}}, \mathrm{x}_{\mathrm{t}}$, and im $\mathrm{t}_{\mathrm{t}}$ Government spending $\mathrm{g}_{\mathrm{t}}$ and the foreign variables $\mathrm{p}_{\mathrm{t}}{ }^{*}, \mathrm{y}_{\mathrm{t}}{ }^{*}, \mathrm{R}_{\mathrm{t}}{ }^{*}$ are taken to be exogenous—as are the shock processes for $\mathrm{v}_{\mathrm{t}}, \mathrm{a}_{\mathrm{t}}, \mathrm{e}_{\mathrm{t}}$, and $\xi_{\mathrm{t}}{ }^{18}$

\footnotetext{
${ }^{17}$ See Fuhrer and Moore (1995), Gali and Gertler (1999), and Woodford (2003).

${ }^{18}$ During the past few years, several quantitative optimizing open-economy models have been developed that are more sophisticated and complex than ours. Outstanding examples include Kollmann (2002), Laxton and Pesenti (2003), and Smets and Wouters (2002).
} 
One might note parenthetically a few features of the model. First, it would be possible to append a money demand function such as

$$
\mathrm{m}_{\mathrm{t}}-\mathrm{p}_{\mathrm{t}}=\gamma_{0}+\gamma_{1} \mathrm{y}_{\mathrm{t}}+\gamma_{2} \mathrm{R}_{\mathrm{t}}+\eta_{\mathrm{t}}
$$

and one of this general form - perhaps with $\mathrm{c}_{\mathrm{t}}$ replacing $\mathrm{y}_{\mathrm{t}}$ - could be consistent with optimizing behavior. But, as many writers have recognized, that equation would serve only to determine the values of $m_{t}$ that are needed to implement the $R_{t}$ policy rule. Second, with the structure given above, a useful measure of the foreign trade balance on goods and services account—i.e., net exports—is

$$
\text { net }_{\mathrm{t}}=\mathrm{x}_{\mathrm{t}}-\left(\mathrm{im}_{\mathrm{t}}+\mathrm{q}_{\mathrm{t}}\right)
$$

where it is assumed that $\omega_{3}=\omega_{4}$. This measure is used in what follows. Also, it is possible to calculate the log of the GDP deflator as

$$
p_{t}^{\text {DEF }}=\left[p_{t}-\omega_{3}\left(s_{t}+p_{t}^{*}\right)\right] /\left(1-\omega_{3}\right) \text {. }
$$

Finally, it might be said that an advantage of the M\&N strategy of modelling imports as material inputs to the production process is that the relevant price index for produced goods is the same as the consumer price index, which implies that the same gradual price adjustment behavior is relevant for all domestic consumption. Such advantages would not constitute a satisfactory justification, of course, if in fact most imports were consumption goods. This is not the case, however, at least for the United States. Instead, an examination of the data suggests that (under conservative assumptions) intermediate productive inputs actually comprise a larger fraction of U.S. imports than do consumer goods (including services). ${ }^{19}$

\footnotetext{
${ }^{19}$ For the year 1998, imported consumer goods amounted to $\$ 453$ billion while imports of business inputs came to $\$ 624$ billion, approximately. These figures are based on an examination of categories reported in the August 1999 issue of the Survey of Current Business. For several categories it is clear whether they are composed
} 
There is one way in which the model developed in M\&N (1999) differs significantly from the 10-equation formulation just presented. Specifically, the former includes a somewhat more complex form of consumption vs. saving behavior, one that features habit formation. Thus in place of the time-separable utility function that leads to equation (12), $M \& N$ assumed that each period-t utility term includes $C_{t} /\left(C_{t-1}\right)^{h}$, with $0 \leq h<1$, rather than $C_{t}$ alone. That specification gives rise to the following replacement for (12):

$$
c_{t}=h_{0}+h_{1} c_{t-1}+h_{2} E_{t} c_{t+1}+h_{3} E_{t} c_{t+2}+h_{4}\left(\log \lambda_{t}\right)+v_{t}
$$

In the latter, $\lambda_{t}$ is the Lagrange multiplier on the household's budget constraint, which obeys

$$
\log \lambda_{\mathrm{t}}=\text { const. }+\mathrm{E}_{\mathrm{t}} \log \lambda_{\mathrm{t}+1}+\mathrm{r}_{\mathrm{t}}
$$

and there are constraints relating the $h_{j}$ parameters to others in the system. ${ }^{20}$ Inclusion of this feature results in a model in which there is somewhat more persistence in consumption and output fluctuations than with the basic formulation. In the present study, accordingly, I have again included this habit-formation modification in the base-case model.

\section{Calibration and Model Properties}

Calibration of the model draws on M\&N (1999) but differs in several ways that are appropriate for present purposes. For the parameter governing spending behavior, I retain here the $\mathrm{h}=0.8$ value taken from an early version of Fuhrer (2000), but for my base case have adopted the assumption that $\gamma$, the counterpart of $-b_{1}$ in (1), equals 0.5 rather than $1 / 6$, in order to reflect the greater responsiveness of investment spending (since the latter is not

predominantly of consumer or business goods. For others, judgemental assignments were required. Those assignments are as follows, with the reported figure being the fraction of the category classified as "business inputs:" Automotive vehicles, engines, and parts, 25\%; Travel, 25\%; Passenger fares, 25\%; Foods, feed, and beverages, $50 \%$; and Other private services, $75 \%$.

${ }^{20}$ For details and additional discussion, see M\&N (1999a), Amato and Laubach (2004), and the basic study by Fuhrer (2002). 
included explicitly in the model). ${ }^{21}$ For $\sigma$, the elasticity of substitution in production (and therefore the elasticity of import demand with respect to $Q_{t}$ ), I now use 0.6 (instead of 0.333 ) so that, with the same absolute value used for the elasticity of export demand with respect to $\mathrm{Q}_{t}$, the Marshall-Lerner condition is satisfied. In (6), the imported inputs share parameter $\alpha_{2}$ is taken to equal $\omega_{3}$, the share of exports in domestic production. The steady state value of this share of imports (and exports) to domestic production is taken to be 0.15 in our base case, and can be altered to represent differing degrees of openness. For the base-case share of government consumption I take $\omega_{2}=0.2$. Finally, in the price adjustment relation the specification is that $\kappa=0.03$. The latter value is based on my reading of a wide variety of studies, plus conversion into non-annualized fractional terms for a quarterly model. Also, quasi-realistic parameters for a Taylor-style interest rate policy rule will be specified as $\mu_{1}=$ $0.5, \mu_{2}=0.5$, and $\mu_{3}=0.8$, the latter reflecting considerable interest rate smoothing. Below I refer to these as "standard" values, but also include cases with other values for $\mu_{1}$ and $\mu_{3}$. The stochastic processes driving the model's shocks must also be calibrated, of course. For both foreign output and the technology shock, I have specified AR(1) processes with AR parameters of 0.95, rather than the 1.0 values used in M\&N (1999). The innovation standard deviations (SD) are 0.03 and 0.007 , respectively. ${ }^{22}$ The UIP risk premium term $\xi_{\mathrm{t}}$ and the consumption shock $\mathrm{v}_{\mathrm{t}}$ are generated by an $\mathrm{AR}(1)$ processes with $\mathrm{AR}$ parameter 0.5 and innovation standard deviations of 0.02 and 0.01 . Government consumption (in logs) follows an AR(1) process, with AR parameter 0.97 and innovation SD of 0.02. Finally, the $u_{t}$ and $e_{t}$ shock processes are taken to be white noise with SD values of 0.002 and 0.0017 , respectively.

\footnotetext{
${ }^{21}$ The parameter in question, $\gamma$, is the intertemporal elasticity of substitution in consumption when $\mathrm{h}=0$.
} 
Before using the foregoing model to discuss the policy rule (20) developed above, we should briefly investigate its properties with $\theta=0$ (i.e., with a Taylor-style $\mathrm{R}_{\mathrm{t}}$ rule) to establish, if possible, that they are at least moderately consistent with our understanding of the characteristics of actual economies. Consider first the values shown in Table 1, where each cell reports standard deviations, in annualized percentage units, of quarterly observations on the four variables $\Delta \mathrm{p}_{\mathrm{t}}, \widetilde{\mathrm{y}}_{\mathrm{t}}, \mathrm{R}_{\mathrm{t}}$, and $\Delta \mathrm{s}_{\mathrm{t}}$. These SDs are averages across 400 simulations of length 200 (with 50 start-up periods discarded), so they approximate population magnitudes. Since constant terms are all set to zero, the SD values not only indicate the variability of the four variables but can also be thought of as representing rootmean-square targeting errors, for cases in which the policy rule is intended to keep some variable close to a chosen target value. Looking across the first row of cells, we see that increased values of $\mu_{1}$, the policy coefficient attached to inflation, lead to reductions in the average targeting errors for inflation— just as the Taylor style rule is intended to do. Over part of the range increased $\mu_{1}$ values also reduce the variability of the output gap, but with large $\mu_{1}$ magnitudes there is a readily apparent tradeoff (between inflation and output gap stabilization). We also see that increased activism with the interest rate instrument, represented by larger $\mu_{1}$ values, gives rise to greater variability of the interest rate instrument itself, $R_{t}$. Exchange rate depreciation variability is almost unaffected by the magnitude of $\mu_{1}$ when small, but increases sharply when $\mu_{1}$ becomes extremely large. All of these features of the simulation results are consistent with one's understanding of how the model should work.

With respect to the magnitudes themselves, we focus on the second cell in the top row, where $\mu_{1}=0.5$ and the $R_{t}$ smoothing parameter equals 0.8 , because these are the policy-

\footnotetext{
${ }^{22}$ These and other values given in this paragraph are given in terms of quarterly fractional units.
} 
rule values that are intended to be roughly representative of ones found in actual economies such as those of the United States, the euro area, the UK, etc. Doing so, we note that the reported SD values $[2.35,1.96,2.48,18.51]$ are encouragingly similar to statistics for actual economies including the United States over 1955-1996 [2.41, 2.23, 2.80, 12.48] or the euro area $1980-2002[1.44,0.83,1.63,19.28]$ or the UK $1972-2001[6.8,2.3,3.1,14.6] .^{23}$

Also revealing are properties of impulse response functions. In that regard, Figure 1 reports the responses of six model variables to a unit shock in the monetary policy rule for the reference case just described. Since that type of shock is an unexpected upward blip in the interest rate instrument, $\mathrm{R}_{\mathrm{t}}$, it represents an unsystematic and unexpected tightening in monetary policy. Figure 1 indicates that such an event would induce a fall in output that is gradually eliminated, a fall in the inflation rate that returns smoothly to its original level over a number of periods (quarters), a sharp appreciation in nominal and real exchange rates, and an increase in net exports. These are all responses that accord with economists' standard understanding of the effects of an unexpected tightening of monetary policy. Next, in Figure 2, we depict the impulses in response to a positive disturbance in the IS function, i.e., an increase in consumers' desire to consume in the present (relative to the future). In this case, both output and inflation rise and only gradually return to their original values. The nominal interest rate rises, as governed by the policy rule, to help to stabilize these movements in output and inflation. The real exchange rate appreciates and only slowly returns to its original level. Also, net exports fall, as a result of the increased income levels that imply an increased magnitude of import demand.

\footnotetext{
${ }^{23}$ For details, see McCallum (2004), which also shows reasonably good matches with respect to the first autocorrelations of these four variables for the economies mentioned (and also Japan).
} 
In Figure 3, we find responses to a positive technology shock. Real income increases and returns to its initial level only very slowly, since the shock is highly persistent—close to a random walk. Inflation falls slightly, and monetary policy lets the one-period interest rate fall in order to stabilize inflation - to which it responds more strongly than output. The trade balance deteriorates, since import demand is boosted by the increased level of income, and the real exchange value of domestic goods falls, since they are relatively cheaper to produce than before the shock. Finally, in Figure 4 we depict a shock to uncovered interest parity, i.e., an unexpected and unsystematic exogenous depreciation of the nominal exchange rate. Since prices are sticky, this translates into an unexpected depreciation also in the real exchange rate. That induces an increase in net exports and therefore an increase in domestic output, with a very small rise in inflation. ${ }^{24}$

In sum, the responses in Figures 1-4 seem reasonably consistent with those that one would expect from a sensible macro/monetary model of an open economy, and thereby provide substantial encouragement to use of that model for the purpose at hand, i.e., to investigate the stabilizing properties of the MC policy rule (20).

\section{Simulation Results}

The objective now is to presents results, based on analysis of the model just described, illustrating the properties of the MC equation (20) as a monetary policy rule. Ideally, one would like to conduct this analysis with an extended version of the model that includes the nonlinear constraint $R_{t} \geq 0$. At present I do not have the necessary computational resources to proceed in this fashion, so only linear-model results will be

\footnotetext{
${ }^{24}$ Note parenthetically that this type of response does not reflect how net exports would behave in response to a change in the monetary policy rule. McCallum (2003) estimates that an increase in the inflation target rate, intended to be permanent, would induce a decrease in net exports (the opposite of a "beggar-thy- neighbor effect).
} 
reported below. They seem to be sufficient, however, to make the two essential points. These are as follows:

(i) Under conditions implying that monetary policy via an interest rate rule would be immobilized by the ZLB constraint, the MC rule will provide policy actions that are strongly stabilizing.

(ii) Under conditions such that the ZLB constraint is not relevant, the MC rule would not significantly—if at all—hinder monetary policy. Together, these two points appear to establish the potential desirability of the MC rule (20). To develop point (i), the procedure is to conduct simulations in which (20) is the policy rule and the interest rate $\mathrm{R}_{\mathrm{t}}$ is held fixed at a constant value. For this to be done, one of the structural equations of the model must as a computational matter be eliminated. As in McCallum (2000), the one chosen is the UIP condition (19). As in that previous case, however, the actual conceptual step is not the elimination of UIP but instead its modification to a more general condition, involving some element of the "portfolio balance" theory, together with recognition that it is operationally redundant. ${ }^{25}$ (Discussion is provided below.) The relevant simulation results are presented in Tables 2 and 3. In the first of these the policy parameters $\mu_{2}$ and $\mu_{3}$ are held fixed at the values 0.5 and 0.8 , respectively, so that the results are comparable to those in the upper cell row of Table 1 . With $\theta=1$, as in the first cell row of Table 2, the MC rule is simply a rule for setting the rate of depreciation (or appreciation) of the exchange rate. The figures in this cell row indicate that with $\mu_{1}$ at the "realistic" value of 0.5 , both inflation and the output gap are excessively variable (in relation to actuality and to the comparable values in Table 1). But the entries in the first cell row of 
Table 2 also show clearly that inflation is effectively stabilized by moving to increased (more aggressive) values of $\mu_{1}$, a result implying that effective stabilization can be provided by the exchange rate rule. Crucially, use of smaller values for $\theta$ in the rule have effects that, when $\mathrm{R}_{\mathrm{t}}=0$, are in some respects similar to those from adoption of larger $\mu_{1}$ magnitudes. Thus while keeping $\mu_{1}=0.5$ we look with interest to the other cell rows in Table 2 , where smaller $\theta$ values are specified, and find much improved performance. With $\theta=0.1$, for example, the SD values for inflation and the output gap are reduced to magnitudes close to those in the second column of Table 1 . In fact, with $\theta=0.025$, the MC rule SD values with $\mu_{1}=0.5$ dominate ${ }^{26}$ those in Table 1. The same is true, moreover, for $\mu_{1}=0.05$. With large values of $\mu_{1}$, however, small $\theta$ settings have the effect of making $\Delta \mathrm{s}_{\mathrm{t}}$ excessively responsive to fluctuations in inflation and the output gap, leading to large SD values for this instrument variable.

The foregoing comparisons are all based on the assumption that $\mu_{3}=0.8$, i.e., that there is considerable smoothing of short-term interest rates. Table 3 provides values analogous to those of Table 2 but with $\mu_{3}=0$, i.e., no smoothing. In this case there is apparently no possibility of literally dominating the Table 1 results, i.e., obtaining lower variability for all four variables, $\Delta \mathrm{p}_{\mathrm{t}}, \tilde{\mathrm{y}}_{\mathrm{t}}, \mathrm{R}_{\mathrm{t}}$, and $\Delta \mathrm{s}_{\mathrm{t}}$. Results are quite encouraging, nevertheless, with small values of $\theta$ and $\mu_{1}$. In any event, the main point of interest is not whether performance is better than with an $\mathrm{R}_{\mathrm{t}}$ instrument in the absence of any ZLB problem. It is, instead, whether the rule (20) can provide stabilizing power even with $R_{t}$ immobilized by the ZLB constraint. Table 3, like Table 2, indicates that such stabilization is indeed

\footnotetext{
${ }^{25}$ In this case the exogenous variability provided by the UIP shock term $\xi_{\mathrm{t}}$ is not eliminated, but instead is transferred to the policy rule (and included in addition to the $e_{t}$ term).
} 
provided, since the SD of inflation falls sharply as we move to the right (by increasing the $\mu_{1}$ parameter values) or downward (by decreasing $\theta$ ).

The second task, involving point (ii), is to show that, in the absence of a ZLB situation, use of MC rule (20) would not seriously hinder the stabilizing effects of monetary policy, relative to the standard case with an interest rate instrument. The relevant simulations now do not impose any ZLB feature at all. ${ }^{27}$ The results for the case with interest rate smoothing $\left(\mu_{3}=0.8\right)$ are shown in Table 4 . These are to be compared with the SD values in the top cell row of Table 1, which are for the standard interest rate rule with smoothing. Consider column two, with the realistic value of 0.5 for $\mu_{1}$. With $\theta=1.0$, we have the case in which the MC rule amounts to a pure exchange-rate rule and we find that variability of inflation and the output gap is distinctly higher than in Table 1 for the same $\mu_{1}$ value. But if we set $\theta=0.1$, as in row two of Table 4 , the MC results improve sharply and would no longer be considered to be significantly worse, relative to the case with a pure $\mathrm{R}_{t}$ rule. So this result tends to establish the point at hand, that serious deterioration is not induced by use of the MC rule when it is unnecessary. Furthermore, the results are better even than that, for with $\theta=0.025$, the SD values from rule (20) are as low or lower (than in Table 1) for all four variables. Thus the MC rule is unambiguously more effective than the $\mathrm{R}_{\mathrm{t}}$ rule in this particular case, even without taking any account of the former's crucial advantage, namely, to be usable in cases in which the ZLB constraint is in effect. ${ }^{28}$

Analogous results are presented in Table 5 under the assumption that $\mu_{3}=0$, rather

\footnotetext{
${ }^{26}$ I.e., are all smaller than.

${ }^{27}$ The outcomes are, accordingly, more favorable than if the possibility of a ZLB were correctly recognized (i.e., the constraint $R_{t} \geq 0$ was actually imposed). But in light of (i), the outcomes reported are relatively more favorable for the reference case with $\theta=0$ and so our conclusion is conservative (i.e., the error works against our conclusion).
} 
than $\mu_{3}=0.8$. The conclusions are much the same. With respect to the results in both Tables 4 and 5 it must be recognized that comparisons that do not impose any ZLB constraint are not the same as the ones that would be fully appropriate theoretically, i.e., comparisons of the $\mathrm{R}_{\mathrm{t}}$ and $\mathrm{MC}$ rules with solutions that have the ZLB constraint binding occasionally. But it would appear that the comparison being made is conservative (in the sense of working against our argument) since there is less weight assigned to the interest rate component by the $\mathrm{MC}$ rule than with the reference case, and this component's stabilizing power should actually be excluded.

The main findings presented to this point are that the MC rule does provide effective stabilization even with $\mathrm{R}_{\mathrm{t}}$ at the ZLB and that the MC rule can perform at least nearly as well as the $R_{t}$ rule when the ZLB is irrelevant. There are many ways in which one would like to check the robustness of these findings with respect to alterations in the model utilized. One that will be considered here is to introduce a somewhat more realistic assumption with respect to information available to the model's monetary policy makers. In particular, it will be assumed that the central bank cannot observe current values of inflation and the output gap when choosing instrument settings for the current period. In rule (20), that is, $\mathrm{E}_{\mathrm{t}-1} \Delta \mathrm{p}_{\mathrm{t}}$ and $\mathrm{E}_{\mathrm{t}-1} \widetilde{\mathrm{y}}_{\mathrm{t}}$ will be used in place of actual values of $\Delta \mathrm{p}_{\mathrm{t}}$ and $\widetilde{\mathrm{y}}_{\mathrm{t}}$. Results are shown in Table 6, all based on the policy-rule parameter values $\mu_{1}=0.5, \mu_{2}=0.5$, and $\mu_{3}=0.8$. In the first column we find SD values under the assumption that the ZLB is irrelevant. The pure interest rate rule case appears in the last cell row $(\theta=0)$, and the other rows show that with small values of $\theta$ there is no substantial deterioration in performance from use of the MC rule (20). Then in column two we have results for the case in which the ZLB condition $R_{t}=0$ is imposed.

${ }^{28}$ A caveat should be mentioned, namely, that the results of our simulations are subject to sampling error. 
Here again we see that the $\mathrm{MC}$ rule is effective, in the sense that $\mathrm{SD}$ values for inflation and the output gap are reduced as the specified value of $\theta$ is decreased, despite the assumed immobilization of the interest rate.

The one other model modification that is explored in the present paper concerns the economy's openness, as measured by $\omega_{3}$, the average share of output that is exported (and imported). In the simulations for Table 6 , this share is doubled to 0.30 . The results reported in columns three and four are analogous to those in columns one and two. And again they are supportive of the suggestion that the MC rule (20) could be useful in improving macroeconomic performance for an economy that has some danger of a ZLB constraint arising.

\section{Analytical Issues}

There are a few theoretical issues, bypassed in the foregoing presentation, that need to be discussed. The first of these has to do with the "elimination" of the UIP condition (19) in the solutions in which the ZLB constraint is imposed. In that regard, most analysts (including myself) would normally include UIP as one component of an open-economy macroeconomic model — despite the existence of much empirical evidence that is, at least on the surface, strongly inconsistent with UIP on a quarter-to-quarter basis. So how can UIP legitimately be avoided here? The answer is as follows.

It is well known that to be consistent with the data, UIP relations must include a discrepancy term, typically referred to as a risk premium. Thus included in (19) is a risk premium $\xi_{\mathrm{t}}$ that has a large variance relative to other shock terms and furthermore is serially correlated. Often $\xi_{\mathrm{t}}$ is treated as exogenous, but there are plausible reasons for believing that

Differences of less than 2-3 percent between values should not, accordingly, be taken too seriously. 
it would be related to the relative amounts of outside domestic and foreign nominal liabilities outstanding. For example, a hypothesis widely entertained during the 1970s might be expressed as

$$
\xi_{\mathrm{t}}=\lambda\left[\mathrm{B}_{\mathrm{t}}-\left(\mathrm{B}_{\mathrm{t}}^{*}+\mathrm{s}_{\mathrm{t}}\right)\right]+\zeta_{\mathrm{t}}
$$

where $\mathrm{B}_{\mathrm{t}}$ and $\mathrm{B}_{\mathrm{t}}{ }^{*}$ are logs of domestic and foreign government debt (including base money) and $\zeta_{\mathrm{t}}$ is an exogenous stochastic shock term. Substituting and recognizing that lags could be involved, we then write

$$
\mathrm{R}_{\mathrm{t}}-\mathrm{R}_{\mathrm{t}}^{*}=\left(\mathrm{E}_{\mathrm{t}} \mathrm{S}_{\mathrm{t}+1}-\mathrm{s}_{\mathrm{t}}\right)+\lambda(\mathrm{L})\left[\mathrm{B}_{\mathrm{t}}-\mathrm{B}_{\mathrm{t}}^{*}-\mathrm{s}_{\mathrm{t}}\right]+\zeta_{\mathrm{t}},
$$

which is similar to equations prominent in several older writings of Dornbusch (e.g., 1987, p.

7). This "portfolio balance" hypothesis has receded from its earlier prominence because various empirical studies failed to find empirical support. But it is, I suggest, quite reasonable to believe that some such relation obtains in fact, probably with weak or transitory effects of the $B_{t}-B_{t}^{*}$ variable. And if such is the case, then our procedure above is fully justified. For (28) indicates that even with $R_{t}=0, s_{t}$ can be affected by central bank purchases of foreign exchange since they alter the value of $B_{t}-B_{t}{ }^{*}$. Yet the precise specification of relation (28) need not be known, and the relation need not be included in the model, for exactly the same reason that money demand functions are not needed in analyses that presume use of an interest rate instrument. Thus appending (28) to the model would have no effect on the implied behavior of $\Delta \mathrm{p}_{\mathrm{t}}, \mathrm{x}_{\mathrm{t}}, \mathrm{y}_{\mathrm{t}}$, or $\Delta \mathrm{s}_{\mathrm{t}}$; it would merely specify the magnitude of open-market purchases of foreign exchange needed to implement the MC policy rule (20). In the present context, this conclusion is important because it implies that our model, with the implicit adoption of (27) and (28), features additional state variables relative to the case in which pure UIP holds, and is therefore not one to which the Eggertsson 
and Woodford (2003, 2004) invariance proposition applies.

Another issue neglected above concerns the argument, developed in the context of a closed economy model, of Benhabib, Schmitt-Grohe, and Uribe (2001). In a series of papers, these authors have suggested that a ZLB situation could arise for reasons quite different from those presumed above. In our analysis, as in that of Krugman (1998), Eggertsson amd Woodford (2003, 2004), Auerbach and Obstfeld (2004), Coenen and Wieland (2003), and most other writers on the ZLB issue, it is assumed that the relevant RE solution is one in which inflation fluctuates around the target value specified by the usual interest rate policy rule. If the target inflation rate plus the steady state real rate of interest is a moderately high value, such as 4-5 percent per year, unusually large shocks would be required to push the system to the vicinity of the ZLB. By contrast, Benhabib, Schmitt-Grohe, and Uribe suggest that there are multiple RE equilibria and the relevant one may instead be located at the ZLB value of $R_{t}$, even in the absence of shocks. My position, argued most extensively in McCallum (2002), is that this ZLB equilibrium is not plausible, because it fails to be E-stable in the sense developed by Evans and Honkapohja (2001). Such a failure implies that this (apparent) RE equilibrium would not be learnable in a setting that recognizes that individual are not miraculously endowed with knowledge of the economy's parameters, but need to learn about them over time by observation of the economy's behavior. The usual RE equilibrium, focused upon by the other papers mentioned above, is by contrast E-stable and learnable under standard assumptions. On the basis of this contrast, I would argue that the usual RE equilibrium is the only one of these two that is plausible as a description of the behavior of an actual economy. 


\section{Conclusions}

Let us close with a brief summary of the paper's arguments. It begins by emphasizing the difference between policy rule changes, intended to help escape an existing ZLB situation, and maintained policy rules designed so as to avoid the "liquidity trap" aspects of a ZLB situation. Analysis assuming that rule changes would be quickly recognized, understood, and believed — so that a new RE equilibrium would be relevant immediately—seems implausible. Accordingly, the paper focuses not on policy changes for escaping a liquidity trap, but on the design of a policy rule that should retain stabilization effectiveness for monetary policy even if the economy is temporarily shocked into a situation in which the zero lower bound on nominal interest rates makes demand stimulation via interest rate reductions infeasible.

The particular policy rule considered in detail is one that uses as its instrument or indicator variable a weighted average of the usual short-term interest rate and the rate of depreciation of the nominal exchange rate. With a small weight attached to the depreciation term, inclusion of the latter would be nearly irrelevant in normal situations. But when the ZLB condition $\mathrm{R}_{\mathrm{t}}=0$ prevails, then adjustments in the weighted average—which has some similarities to a monetary conditions index-require large movements in the depreciation rate (effected by central bank purchases of foreign exchange). These would affect aggregate demand by another channel, and would provide stabilization power-with no need for any additional exit strategy.

Stabilizing properties of this MC rule are studied by means of stochastic simulations with a model of a small open economy developed by McCallum and Nelson (1999). The 
latter differs from other small-scale models based on optimizing behavior (but with sticky prices) by treating imports as inputs to the economy's production processes, rather than as consumer goods. The simulations indicate that: (i) under conditions implying that monetary policy via an interest rate rule would be immobilized by the ZLB constraint, the MC rule would provide strong stabilizing policy actions; yet (ii) under conditions such that the ZLB constraint is not relevant, the MC rule would not significantly—if at all—hinder monetary policy. Together, these two sets of results are supportive of the idea that a monetary policy of the MC type could be useful for an economy with a low target inflation rate. 


\section{$\underline{\text { Appendix A }}$}

The object here is to briefly discuss the effectiveness of "helicopter drop" policy for escaping a ZLB situation. Would such a policy be successful? I suggest that it would be ineffective if the economy possesses Ricardian properties, as in the case of the canonical model used by E\&W (2003) and many others. The first step of the argument is as follows.

A "helicopter drop" is a transfer (gift) of money to households. In this regard, note that a transfer of $\$ \mathrm{~K}$ is equivalent to the combination of two operations, namely, (i) A lump-sum tax reduction of $\$ \mathrm{~K}$ financed by the sale of $\$ \mathrm{~K}$ of $\mathrm{T}$-bills to households (i.e., a gift of \$K of T-bills to households), and

(ii) An open-market purchase of $\$ \mathrm{~K}$ worth of T-bills.

But, it is well known that (i) has no effect if the economy is Ricardian and that (ii) has no effect at the ZLB (where base money and T-bills are perfect substitutes at the margin). Thus the combined operation — the helicopter drop-will have no effect.

The second step of the argument concerns a sequence of such operations. Wouldn't an ongoing sequence violate a transversality condition if there were no inflationary effect, since the nominal money stock is growing without bound in the proposed experiment? Well, yes, it would if the ZLB situation were to go on forever. But analysis of ZLB issues typically pertains to situations in which an economy, with a positive steady-state nominal interest rate, is at the ZLB as the result of some negative shock. In such cases, the economy will escape the ZLB of its own accord at some point in the finite future, after which time $\mathrm{p}_{\mathrm{t}}$ will tend to grow in line with $\mathrm{m}_{\mathrm{t}}$. So, since transversality results pertain to the infinite future they are not relevant. [One could obtain effects from repeated helicopter drops by using a non-Ricardian model, such as the overlapping-generations model used in McCallum (2000, pp. 876-880).] 


\section{Table 1}

Results with Standard Interest Rate Rule

Cell entries are standard deviations of $\Delta \mathrm{p}_{t}, \tilde{y}_{t}, \mathrm{R}_{\mathrm{t}}, \& \Delta \mathrm{s}_{\mathrm{t}}$

\begin{tabular}{|c|c|c|c|c|}
\hline & $\mu_{1}=0.05$ & $\mu_{1}=0.5$ & $\mu_{1}=5.0$ & $\mu_{1}=50.0$ \\
\hline$\mu_{3}=0.8$ & 3.28 & 2.35 & 1.36 & 0.74 \\
& 2.19 & 1.96 & 1.69 & 2.35 \\
& 2.82 & 2.48 & 3.82 & 11.26 \\
& 18.59 & 18.51 & 19.35 & 27.70 \\
\hline$\mu_{3}=0.0$ & 6.27 & 2.92 & 1.35 & 0.58 \\
& 2.07 & 1.68 & 1.54 & 3.01 \\
& 7.03 & 4.70 & 7.80 & 28.16 \\
& 19.14 & 18.56 & 21.97 & 46.82 \\
\hline
\end{tabular}


Table 2

Results with MC Rule (20) when $\Delta \mathrm{R}_{\mathrm{t}}=0$ (with $\mu_{3}=0.8$ )

Cell entries are standard deviations of $\Delta \mathrm{p}_{\mathrm{t}}, \tilde{\mathrm{y}}_{\mathrm{t}}$, and $\Delta \mathrm{s}_{\mathrm{t}}$

\begin{tabular}{|c|c|c|c|c|}
\hline & $\mu_{1}=0.05$ & $\mu_{1}=0.5$ & $\mu_{1}=5.0$ & $\mu_{1}=50.0$ \\
\hline$\theta=1.0$ & 34.41 & 9.87 & 2.32 & 0.79 \\
& 13.28 & 4.53 & 2.38 & 2.73 \\
& 31.75 & 10.38 & 11.02 & 38.21 \\
\hline$\theta=0.1$ & 3.44 & 2.65 & 1.31 & 0.48 \\
& 2.44 & 2.27 & 2.20 & 3.54 \\
& 8.33 & 9.45 & 19.81 & 65.56 \\
\hline$\theta=0.025$ & 1.60 & 1.38 & 0.78 & 0.26 \\
& 1.81 & 1.86 & 2.47 & 4.64 \\
& 14.69 & 17.26 & 36.44 & 103.75 \\
\hline$\theta=0.01$ & 1.16 & 1.02 & 0.57 & 0.16 \\
& 1.63 & 1.81 & 2.94 & 5.33 \\
& 22.17 & 26.10 & 53.72 & 128.61 \\
\hline
\end{tabular}

Table 3

Results with MC Rule (20) when $\Delta \mathrm{R}_{\mathrm{t}}=0$ (with $\mu_{3}=0$ )

Cell entries are standard deviations of $\Delta \mathrm{p}_{\mathrm{t}}, \tilde{\mathrm{y}}_{\mathrm{t}}$, and $\Delta \mathrm{s}_{\mathrm{t}}$

\begin{tabular}{|c|c|c|c|c|}
\hline & $\mu_{1}=0.05$ & $\mu_{1}=0.5$ & $\mu_{1}=5.0$ & $\mu_{1}=50.0$ \\
\hline$\theta=1.0$ & 34.41 & 9.87 & 2.32 & 0.79 \\
& 13.28 & 4.53 & 2.38 & 2.73 \\
& 31.75 & 10.38 & 11.02 & 38.21 \\
\hline$\theta=0.1$ & 1.51 & 1.30 & 0.74 & 0.24 \\
& 1.79 & 1.83 & 2.55 & 4.77 \\
& 15.78 & 18.42 & 38.99 & 108.04 \\
\hline$\theta=0.025$ & 1.03 & 0.90 & 0.48 & 0.11 \\
& 1.63 & 1.90 & 3.31 & 5.66 \\
& 28.46 & 33.24 & 67.52 & 141.37 \\
\hline$\theta=0.01$ & 0.95 & 0.82 & 0.40 & 0.08 \\
& 1.71 & 2.06 & 3.72 & 5.94 \\
& 36.29 & 42.46 & 83.21 & 152.08 \\
\hline
\end{tabular}


Table 4

Results with MC Rule (20) with No ZLB $\left(\mu_{3}=0.8\right)$

Cell entries are standard deviations of $\Delta \mathrm{p}_{\mathrm{t}}, \tilde{\mathrm{y}}_{\mathrm{t}}, \mathrm{R}_{\mathrm{t}}, \Delta \mathrm{s}_{\mathrm{t}}$

\begin{tabular}{|c|r|r|r|r|}
\hline & $\mu_{1}=0.05$ & $\mu_{1}=0.5$ & $\mu_{1}=5.0$ & $\mu_{1}=50.0$ \\
\hline$\theta=1.0$ & 10.39 & 3.63 & 1.45 & 0.62 \\
& 2.63 & 2.41 & 2.17 & 3.15 \\
& 12.84 & 9.32 & 10.97 & 19.87 \\
& 9.36 & 1.65 & 6.22 & 29.87 \\
\hline$\theta=0.1$ & 2.92 & 2.26 & 1.29 & 0.69 \\
& 2.16 & 1.94 & 1.73 & 2.51 \\
& 2.61 & 2.69 & 4.26 & 12.63 \\
& 16.94 & 16.42 & 17.30 & 24.41 \\
\hline$\theta=0.025$ & 3.13 & 2.31 & 1.34 & 0.73 \\
& 2.19 & 1.96 & 1.69 & 2.39 \\
& 2.61 & 2.41 & 3.88 & 11.60 \\
& 18.22 & 18.01 & 18.87 & 27.91 \\
\hline$\theta=0.01$ & 3.20 & 2.31 & 1.36 & 0.74 \\
& 2.19 & 1.95 & 1.68 & 2.37 \\
& 2.73 & 2.41 & 3.84 & 11.39 \\
& 18.38 & 18.39 & 19.19 & 27.69 \\
\hline
\end{tabular}

Table 5

Results with MC Rule (20) with No ZLB ( $\left.\mu_{3}=0.0\right)$

Cell entries are standard deviations of $\Delta p_{t}, \tilde{y}_{t}, R_{t}, \Delta s_{t}$

\begin{tabular}{|c|c|c|c|c|}
\hline & $\mu_{1}=0.05$ & $\mu_{1}=0.5$ & $\mu_{1}=5.0$ & $\mu_{1}=50.0$ \\
\hline$\theta=1.0$ & 10.39 & 3.63 & 1.45 & 0.62 \\
& 2.63 & 2.41 & 2.17 & 3.15 \\
& 12.84 & 9.32 & 10.97 & 19.87 \\
& 9.36 & 1.65 & 6.22 & 29.87 \\
\hline$\theta=0.1$ & 5.79 & 2.74 & 1.28 & 0.55 \\
& 2.03 & 1.67 & 1.57 & 3.05 \\
& 6.91 & 4.94 & 7.74 & 27.14 \\
& 18.28 & 17.57 & 20.67 & 45.76 \\
\hline$\theta=0.025$ & 6.19 & 2.88 & 1.33 & 0.57 \\
& 2.06 & 1.65 & 1.55 & 3.01 \\
& 6.98 & 4.69 & 7.72 & 27.96 \\
& 18.97 & 18.47 & 21.52 & 46.89 \\
\hline$\theta=0.01$ & 2.30 & 2.91 & 1.33 & 0.58. \\
& 2.07 & 1.67 & 1.54 & 3.02 \\
& 6.98 & 4.69 & 7.68 & 28.20 \\
& 19.10 & 18.58 & 21.72 & 47.17 \\
\hline
\end{tabular}


Table 6

MC Rule (20) with Model Alterations $\left(\mu_{1}=0.5 ; \mu_{3}=0.8\right)$

Cell entries are standard deviations of $\Delta \mathrm{p}_{\mathrm{t}}, \tilde{\mathrm{y}}_{\mathrm{t}}, \mathrm{R}_{\mathrm{t}}$, and $\Delta \mathrm{s}_{\mathrm{t}}$

\begin{tabular}{|c|c|c|c|c|}
\hline & $\begin{array}{c}\text { Case with } \\
\mathrm{E}_{\mathrm{t}-1} \Delta \mathrm{p}_{\mathrm{t}} \text { and } \\
\mathrm{E}_{\mathrm{t}-1} \tilde{\mathrm{y}}_{\mathrm{t}} \text { in } \\
\text { policy rule. } \\
\text { No ZLB. }\end{array}$ & $\begin{array}{l}\text { Case with } \\
\mathrm{E}_{\mathrm{t}-1} \Delta \mathrm{p}_{\mathrm{t}} \text { and } \\
\mathrm{E}_{\mathrm{t}-1} \tilde{\mathrm{y}}_{\mathrm{t}} \text { in } \\
\text { policy rule. } \\
\mathrm{ZLB}, \mathrm{R}_{\mathrm{t}}=0\end{array}$ & $\begin{array}{l}\text { Case with } \\
\omega_{3}=0.30 \\
\text { No ZLB }\end{array}$ & $\begin{array}{c}\text { Case with } \\
\omega_{3}=0.30 \\
\text { ZLB, } \\
\mathrm{R}_{\mathrm{t}}=0\end{array}$ \\
\hline $\begin{array}{l}\theta=1.0 \\
\Delta s_{t} \text { rule }\end{array}$ & $\begin{array}{l}3.66 \\
2.51 \\
9.31 \\
1.46\end{array}$ & $\begin{array}{r}9.85 \\
4.61 \\
0.00 \\
10.30\end{array}$ & $\begin{array}{l}3.23 \\
2.21 \\
9.26 \\
1.55\end{array}$ & $\begin{array}{r}9.69 \\
4.70 \\
0.00 \\
10.33\end{array}$ \\
\hline$\theta=0.1$ & $\begin{array}{r}2.49 \\
2.08 \\
2.56 \\
16.77\end{array}$ & $\begin{array}{r}3.00 \\
2.54 \\
0.00 \\
10.43\end{array}$ & $\begin{array}{r}2.13 \\
2.26 \\
2.68 \\
15.56\end{array}$ & $\begin{array}{l}2.32 \\
2.30 \\
0.00 \\
7.82\end{array}$ \\
\hline$\theta=0.025$ & $\begin{array}{r}2.58 \\
2.07 \\
2.25 \\
18.54\end{array}$ & $\begin{array}{r}1.75 \\
2.18 \\
0.00 \\
17.78\end{array}$ & $\begin{array}{r}2.16 \\
2.32 \\
2.24 \\
17.23\end{array}$ & $\begin{array}{r}1.12 \\
1.86 \\
0.00 \\
11.18\end{array}$ \\
\hline$\theta=0.01$ & $\begin{array}{r}2.61 \\
2.30 \\
2.29 \\
18.78\end{array}$ & $\begin{array}{r}1.41 \\
2.07 \\
0.00 \\
25.29\end{array}$ & $\begin{array}{r}2.19 \\
2.35 \\
2.27 \\
17.51\end{array}$ & $\begin{array}{r}0.89 \\
1.92 \\
0.00 \\
15.08\end{array}$ \\
\hline $\begin{array}{l}\theta=0.0 \\
R_{t} \text { rule }\end{array}$ & $\begin{array}{r}2.62 \\
2.09 \\
2.33 \\
18.99\end{array}$ & & $\begin{array}{r}2.20 \\
2.36 \\
2.28 \\
17.67\end{array}$ & \\
\hline
\end{tabular}


Figure 1

Impulse Responses, $\mathbf{R}_{\mathrm{t}}$ Rule, Shock to Policy Rule
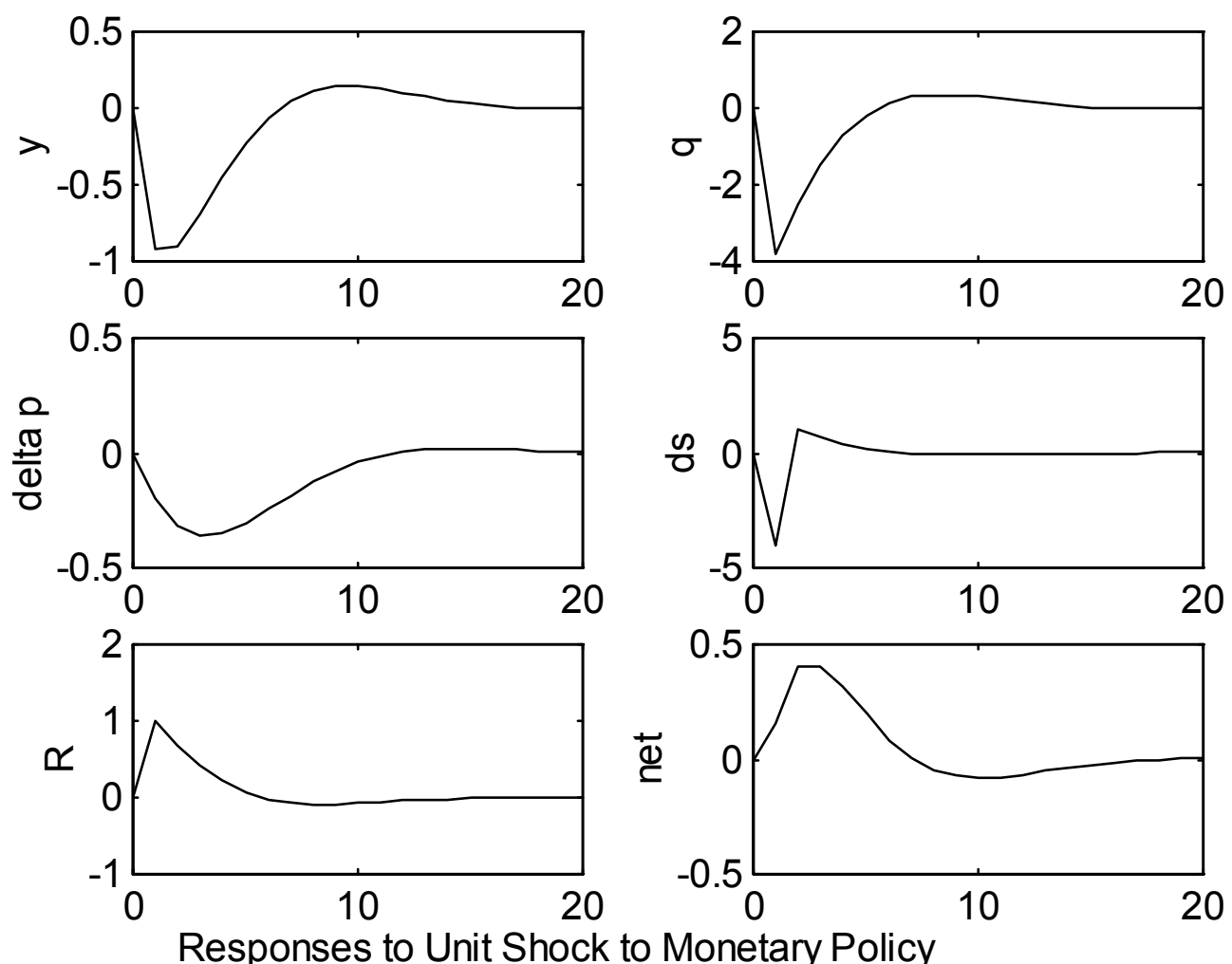
Figure 2

Impulse Responses, $R_{t}$ Rule, Shock to IS Function
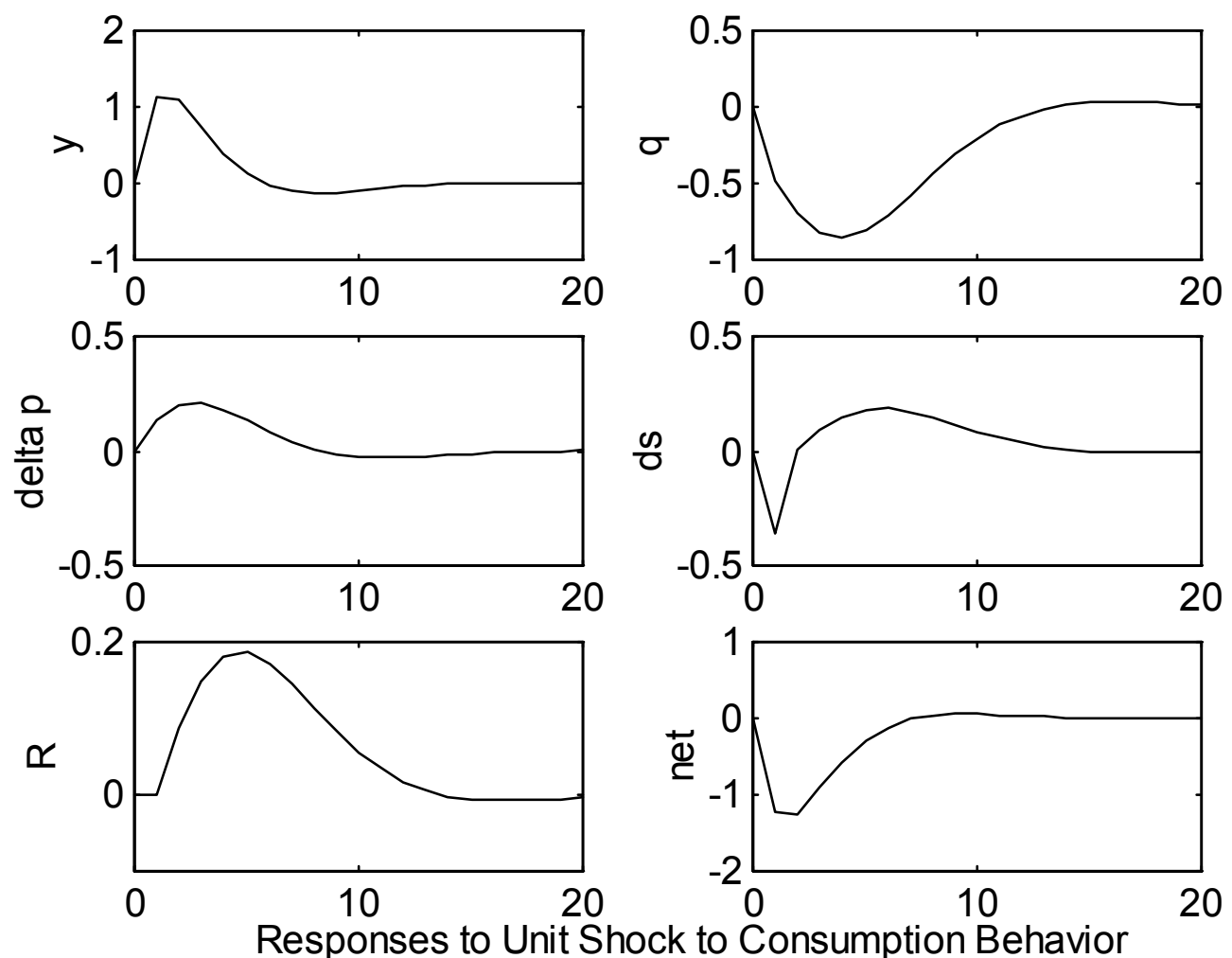
Figure 3

Impulse Responses, $R_{t}$ Rule, Shock to Technology

Figure 4

Impulse Responses, $\mathbf{R}_{t}$ Rule, Shock to Exchange Rate
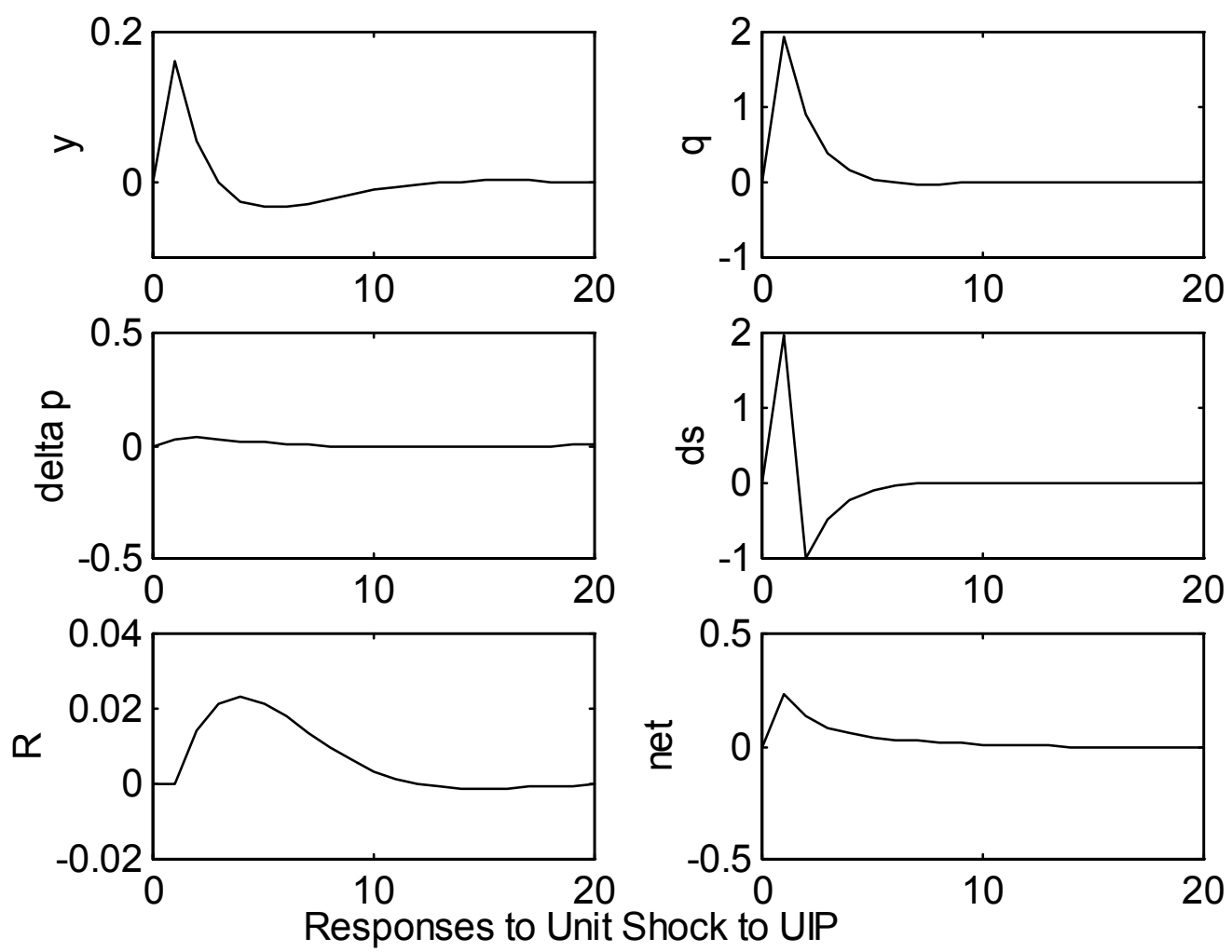


\section{References}

Amato, J.D., and T. Laubach (2004) "Implications of Habit Formation for Optimal Monetary Policy, Journal of Monetary Economics 51, 305-325.

Auerbach, A.J., and M. Obstfeld (2003) "The Case for Open-Market Purchases in a Liquidity Trap," NBER WP 9814.

(2004) "Monetary and Fiscal Remedies for Deflation,"

American Economic Review Papers and Proceedings 94, 71-75.

Ball, L. (1999) "Policy Rules for Open Economies,” In J.B. Taylor, ed., Monetary Policy Rules. Chicago: University of Chicago Press for NBER.

Benhabib, J., S. Schmitt-Grohe, and M. Uribe (2001) “The Perils of Taylor Rules,” Journal of Economic Theory 96, 40-69.

Coenen, G., and V. Wieland (2003) "The Zero-Interest-Rate Bound and the Role of the Exchange Rate for Monetary Policy in Japan," Journal of Monetary Economics 50, 1071 1101.

Detken, C., and V. Gaspar (2003) "Maintaining Price Stability Under Free-Floating: A Fearless Way Out of the Corner?” European Central Bank WP 241.

Dornbusch, R. (1987) “Exchange Rate Economics: 1986,” Economic Journal 97, 1-18.

Eggertsson, G.B., and M. Woodford (2003) "Optimal Monetary Policy in a Liquidity Trap," NBER WP 9968.

(2004) "Policy Options in a Liquidity Trap," American

Economic Review Papers and Proceedings 94, 76-79.

Evans, G.W., and S. Honkapohja (2001) Learning and Expectations in Macroeconomics.

Princeton: Princeton University Press.

Fuhrer, J.C. (2000) "Habit Formation in Consumption and its Implications for MonetaryPolicy Models,” American Economic Review 90, 367-390.

Fuhrer, J.C., and G.R. Moore (1995) “Inflation persistence," Quarterly Journal of Economics 110. 127-159.

Gali, J., and M. Gertler (1999) "Inflation Dynamics: A Structural Econometric Analysis," Journal of Monetary Economics 44, 195-222.

Gerlach, S., and F. Smets (2000) "MCIs and Monetary Policy," European Economic Review 44, 1677-1700. 
Goodfriend, M. (2000) "Overcoming the Zero Bound on Interest Rate Policy," Journal of Money, Credit, and Banking 32, 1007-1035.

Jung, T., Y. Teranishi, and T. Watanabe (2001) "Zero Bound on Nominal Interest Rates and Optimal Monetary Policy," Working Paper, Hitotsubashi University.

Kollmann, R. (2002) "Monetary Policy Rules in the Open Economy: Effects on Welfare and Business Cycles,” Journal of Monetary Economics 49, 989-1015.

Krugman, P. (1998) "It's Baaack! Japan's Slump and the Return of the Liquidity Trap," Brookings Papers on Economic Activity (no.2), 137-187.

Kydland, F.E., and E.C. Prescott (1977) "Rules Rather than Discretion: The Inconsistency of Optimal Plans," Journal of Political Economy 85, 473-491.

Laxton, D., and P. Pesenti (2003) "Monetary Rules for Small, Open, Emerging Economies," Journal of Monetary Economics 50, 1109-1146.

Lucas, R.E., Jr. (1980) "Rules, Discretion, and the Role of the Economic Advisor." In S. Fischer, ed., Rational Expectations and Economic Policy. Chicago: University of Chicago Press.

Lucas, R. E., Jr., and T.J. Sargent (eds.) (1981). Rational Expectations and Econometric Practice. Minneapolis: University of Minnesota Press.

McCallum, B.T. (2000) "Theoretical Analysis Regarding a Zero Lower Bound on Nominal Interest Rates," Journal of Money, Credit, and Banking 32, 870-904.

(2002) "Inflation Targeting and the Liquidity Trap," in N. Loayza and R.

Soto, eds., Inflation Targeting: Design, Performance, Challenges. Central Bank of Chile.

(2003) “Japanese Monetary Policy, 1991-2001,” Federal Reserve Bank of Richmond Economic Quarterly 89 (Winter), 1-31.

(2004) "The Monetary Policy Transmission Mechanism in Industrial Countries,” Working Paper, Carnegie Mellon University.

McCallum, B.T., and E. Nelson (1999) "Nominal Income Targeting in an Open-Economy Optimizing Model," Journal of Monetary Economics 43, 553-578.

and (2000) "Monetary Policy for an Open Economy: An Alternative Framework with Optimizing Agents and Sticky Prices," Oxford Review of Economic Policy 16, 74-91. 
Orphanides, A., and V. Wieland (2000) "Efficient Monetary Policy Design Near Price Stability," Journal of the Japanese and International Economies 14, 327-365.

Reifschneider, D., and J.S. Williams (2000) “Three Lessons for Monetary Policy in a Low Inflation Era," Journal of Money, Credit, and Banking 32, 936-966.

Rotemberg, J.J., and M. Woodford (1997) "An Optimization Based Econometric Framework for the Evaluation of Monetary Policy," NBER Macroeconomics Annual 1997. MIT Press.

Smets, F., and R. Wouters (2002) "Openness, Imperfect Exchange Rate Pass-Through, and Monetary Policy,” Journal of Monetary Economics 49, 947-981.

Svensson, L.E.O. (2001) "The Zero Bound in an Open Economy: A Foolproof Way of Escaping from a Liquidity Trap," Bank of Japan Monetary and Economic Studies 19, 277-312.

Taylor, J.B. (1993) "Discretion Versus Policy Rules in Practice,” Carnegie-Rochester Conference Series on Public Policy 39, 195-214.

Wolman, A.S. (1998) "Staggered Price Setting and the Zero Bound on Nominal Interest Rates," Federal Reserve Bank of Richmond Economic Quarterly 84 (Fall), 1-24.

Woodford, M. (2003) Interest and Prices: Foundations of a Theory of Monetary Policy. Princeton University Press. 